DOI https://doi.org/10.18551/rjoas.2017-06.04

\title{
ANALYSIS OF THE COMPETITIVE ADVANTAGES OF RUSSIAN BUSINESS IN THE FOOD MARKET
}

\author{
Silanteva E.S. \\ Lomonosov Moscow State University, Moscow, Russia \\ E-mail: the best kat@mail.ru
}

\begin{abstract}
In modern conditions, in connection with the aggravation of the political situation and the introduction of food embargo on the goods of major importers, the problem of providing the Russian population with high-quality and affordable food is becoming urgent. This problem is complex, requiring a wide theoretical and historical interpretation. In this regard the historical and economic analyses of the food sector was carried out, the historical reasons for the emergence of dependence on imports in the food market of the Russian Federation was revealed and the main directions of the solution of the problem of providing the population with food were analyzed on the basis of mobilizing of the system of competitive advantages of Russian business and public policy measures. The study is overviewed different approaches to the problem of competitiveness from the point of view of various economic theories. The main opportunities for increasing the competitiveness of Russian business in the food market are also overviewed in article. There are three types of competitive advantages: market, resources and institutional. A company should combine these competitive advantages with a purpose to develop the most successful competitive strategies. The Government should assist the domestic companies in realization of their competitive potential.
\end{abstract}

\section{KEY WORDS}

Food manufacturers, food suppliers, wholesale companies, trade, retail, competitive advantages, competitiveness, competition, national business, market, resources, institutional, competitive strategy.

Problems of the formation of the modern food sphere in Russia are connected with the problems which have arisen in last century. They are: state agriculture, impossibility of ensuring consumer demand, artificial understating of the prices for agricultural production (Serova, 2010). For better understanding of the modern food sphere we should analyze its formation by stages.

In the late 19th early 20th century, the Russian Empire stood on a special place in the food market of Europe, ranking the first place in the world for production of grain bread. Over half of the world's rye, a fifth of the world's wheat crop, a third of barley and a quarter of all oats were also manufactured in Russia. Grain was the main income item and the profit from its sale accounted nearly the half of the income from all exports. In 1913, the Russian Empire exported about 10.5 million tons of grain.

Until the end of the 1950s, the Soviet Union continued to export grain, despite the poor harvest and famine in the countryside. The main task of export was to obtain the currency that was necessary for the country industrialization, and then for the restoration of the national economy destroyed by the Second World War. The collectivization of agriculture that took place in the USSR adversely affected the development of the food sector.

Despite the short-term effect, that helped the state to raise the grain export, to finance industrialization, the consequences of collectivization were extremely severe: a reduction of livestock, as the peasants had to slaughter cattle in order to not surrender it into collective farm property, the mass famine of 1932-1933 The weakening of economic incentives for the development of agricultural production, the alienation of peasants from property and the results of their labor. The breakdown of traditional economic and social ties, ultimately led to a crisis in agriculture and the economic decline that began in the 60 s of the 20th century. 
The policy of virgin lands development, initiated by Nikita Khrushchev, did not give the expected results. The USSR from the net exporter of agricultural products turned into a net importer. Import of grain was carried out due to the income gained from the export of raw materials - oil and gas, as well as goods of industrial production. One of the factors that further influenced the growth of the USSR's import dependency was also the Nikita Khrushchev's politics struggling against households that worsened the well-being of collective farmers, since the personal farms were the main sources of their income. Due to this, outflow of the population from rural areas continued, that affected negatively the state of agriculture.

As for the RSFSR, it was, above all, a net importer of agro-food products - its own production was not enough to provide food security. The state, while maintaining low prices for food, subsidized domestic consumers in increasing proportion. In 1989, the share of subsidies in the retail price of basic foodstuffs reached $80 \%$. At the same time, opinion polls in the village showed that only $10-15 \%$ of rural residents wanted to lead an independent economy.

Agro-food policy in modern Russia should also be considered in stages:

The first stage (1991-1994) began with the liberalization of prices, the elimination of the state procurement system in the agricultural sector, the abolition of mandatory production plans for agricultural enterprises, subsidies and benefits for agriculture. For 1992-1994 about 12 million land plots were distributed. About 300 thousand households took advantage of their right to withdraw from collective farms and organize their own family farms. At the same time, up to $40 \%$ of registered agricultural producers in Russia did not actually conduct economic activities. As a result, a high proportion of low-margin producers remained on the market. Russia received food aid.

At the second stage (1994-1998) - the policy of liberalization began to supplant agrarian protectionism. Russia introduced minimum guaranteed prices, import tariffs and quotas, export subsidies, and stopped receiving humanitarian assistance. The first data on grain exports appeared.

At the third stage (1998-2005) the government began to implement comprehensive measures with clearer objectives. Protectionism began to grow. The devaluation of the ruble led to the crisis of the national economy, but in 1998 the volume of imports to Russia fell by $20 \%$ (to $\$ 74$ billion), in 1999 - by another $28 \%$ (to $\$ 53$ billion). At the same time, the demand for domestic products increased after the crisis and was quite easily satisfied on an extensive basis due to unloaded production capacities. The decline in imports caused by the devaluation was the most important factor of economic growth.

In 2001-2002, Russia for the first time in the new history exported significant volumes of grain - 7.1 million tons, entering the top ten world countries for wheat exports and the top five for barley.

At the fourth stage (from 2006 to 2013), the agrarian budget and trade protectionism continued to grow. In 2006, the agrarian sector was named for the first time among the priorities of the country's development. At the end of December of the same year, the Law "On the Development of Agriculture» was adopted and the State Program for the Development of the Sector

In 2009, the United Grain Company was established, which was called upon to become the largest exporter of Russian grain.

At the fifth stage (starting from 2014), policy of import substitution of food products was announced. The government imposed sanctions against a number of exporting countries, and also partially restricted the export of Russian food (mainly grain).

In modern conditions, import substitution should be based not on prohibitive measures, but on strategic planning of the entire value chain in the food sector, reindustrialization of the economy, technological and innovative breakthrough, and increasing competitiveness of Russian producers. Undoubtedly, the possibility of import substitution of food products is closely related to the ability of the national business to use its competitive advantages.

Implementation of the competitive advantages system. Russian enterprises in the food market could take an advantage from the current political and economic situation and 
increase their internal efficiency and competitiveness through the implementation of the entire complex of competitive advantages (Simanovskaya M., Silanteva E., 2016).

Russian enterprises in the food market along the entire value chain: food manufacturers, suppliers and retailers have a certain competitive potential that can be evaluated from the standpoint of the current market, resources and institutional theories of the competitive advantages of organization. Therefore, they should take advantage of the prevailing protectionist situation and increase their competitiveness through the implementation of the entire system of competitive advantages.

The market competitive advantages of Russian companies in the food market. The market theory of the competitive advantages of the organization, the largest contribution to which was provided by Mikhail Porter (Porter, 1993), is based on the assumption that in order to ensure the company's competitiveness in relation to competitors, it needs to occupy an advantageous position in the industry. In other words, in the concept of Mikhail Porter, the strategy is understood as positioning the business in a stable and well-defined industry structure. In accordance with the concept of market positioning, Russian firms should choose the field of activity, the result of which is not only valuable for consumers, but also help the company to position itself in a competitive environment in the most efficient manner.

The existence of the phenomenon of territorial asymmetry in providing food for the population is the main competitive advantage of Russian food manufacturers. In some regions of the Russian Federation, food import is unprofitable, which is associated with high logistical costs of suppliers.

Parts of the regions in the eastern part of the country are extremely remote from the main importers. This makes impossible to supply, for example, perishable products with a shelf life of several days. They should be manufactured in the domestic conditions.

The resource competitive advantages of Russian companies in the food market. The theory of resources competitive advantages has developed in recent decades. A special contribution to the development of this theory was made by: E.Penrose, C. Prahald and $\mathrm{H}$. Hamel, R. Grant. According to this theory, the priority direction of the company's development is that, where the existing complex of unique resources and capabilities strategically meets the goals of the industry. In the short term, the competitiveness of a firm depends on the price and consumer characteristics of its key products, but in the context of global competition in the long term, competitiveness is based on the ability of the company to create key competencies at lower costs and faster than competitors. On the basis of these competitive advantages unforeseen products are born.

One of the resources competitive advantages of Russian manufacturers are unused production capacities. According to the Russian Grain Union, with grain exports of 30 million tons (2014), Russian infrastructure was potentially capable for processing up to 50 million tons of grain for export, while the share of high-quality, high-protein wheat of grade 3 increased in the structure of exports. Production in Russia is also potentially attractive from the standpoint of cheap labor of sufficiently skilled workers. An important intangible asset of Russian food manufacturers is the loyalty to Russian brands that are familiar to consumers from childhood, such as, for example, «Red October». One of the important resources competitive advantages of Russian manufacturers is relatively cheap electricity and high volume of water resources.

The institutional competitive advantages of Russian companies in the food market. According to the institutional theory of competitive advantages (Katkalo, 2006), economic behavior and economic choice of an organization are determined not only by resource opportunities, but also have an institutional and social nature. The institutional approach is based on the notion that competition in the modern world has an essential element of cooperation, manifested in the activities of companies within the network entities. In modern economy, to create additional competitive advantages, the company should be effectively integrated into the environment and network relationships with other firms, the state and civil society actors. However, the emerging new institutional networks between economic entities are fraught with new serious ethical problems that require deep reflection. In modern Russia, 
attempts to resolve such contradictions are carried out within the framework of various industry and interindustry associations.

The cooperation of Russian food manufacturers has been intensified within the sectors. A striking example of such cooperation is the Association of Food manufacturers and suppliers «Rusprodsoyuz» that unites more than 400 Russian producers and promotes their interests.

The cooperation of Russian food manufacturers also has been intensified within the entire Russian food market. Rusprodsoyuz is the part of the Interindustry Economic Council that elaborates and promotes the strategy of food industry development. This Council also was founder of the "Code of Good Practices" that regulates the relationship between trade and food organizations.

The cooperation of Russian manufacturers with trading enterprises is also carrying out. One of the areas of cooperation of food manufacturers and trade is the "Retailers brands». Retailers buy food of local manufacturers and sell it under their own brands. Often this food is the "cheapest». It is sold under such brands as "Red Price» (Pyaterochka), "Every Day» (Auchan). This direction of trade companies business became especially in demand in conditions of food embargo introduction and a fall of the ruble exchange rate.

The Government supports Russian small and medium-sized companies in the food market. For this purpose, the Federal Trade Law was adopted. The Law protects to a certain extent the interests of small and medium-sized businesses, regulating the relationship between trade organizations and suppliers. One of the protective measures for small and medium-sized companies in the food market is the limited market share of retailers in the regions that should not exceed $25 \%$ in regions. But at the same time, according to experts of the Chamber of Commerce and Industry of the Russian Federation, the current deficit of modern trade formats creates a multitude of problems and difficulties in the relationship between trade and suppliers. Complex of competitive advantages:

An effective competitive strategy of Russian manufacturers should combine competitive advantages of different types regarding not only individual characteristics of the company and industry, but also the economic situation in the country and world. Consideration of competitive advantages based on only one of the approaches may lead to the fact that the company will lose important components of competitiveness.

The main task of the modern economic policy of the state is to create an adequate institutional infrastructure for food complex development. This infrastructure should provide national manufacturers with the opportunity to realize their competitive advantages and also to cooperate in good faith with trading enterprises.

\section{CONCLUSION}

The historical analysis of the food sector formation showed that the problems of the formation of the modern food sphere in Russia arose in the last century and is associated with state agriculture, the inability to provide consumer demand, and the artificial understatement of prices for agricultural products. Liberalization of the economy led to the destruction of the agro-industrial complex, for the reconstruction of which it is necessary for the state to carry out a sound economic policy and increase the competitiveness of Russian business.

Analysis of the Russian food market showed that Russian companies have competitive potential and certain market, resources and institutional competitive advantages. In this regard, the complex use of competitive advantages theory tools in practice is necessary in order to analyze ways to increase the competitiveness of domestic food manufacturers, and create a conscientious trading environment that ensures food security for the population and allows different sizes Russian manufacturers to develop. 


\section{REFERENCES}

1. Grant R. Strategic development. (2011) Saint Petersburg: Piter.

2. Katkalo V., Evolution of the theory of Strategic management, (2006), Saint Petersburg, Publishing house SPBGU.

3. Kleiner G. Resursnaia teoriia sistemnoi organizatsii ekonomiki. Rossiiskii zhurnal menedzhmenta, 2011, t. 4, no 3, pp. 3-28.

4. Penrose E., Pitelis C. The Theory of the Growth of the Firm. Oxford: Oxford University Press, 2009

5. Porter M. Competitive strategy: Methodology of analyses of branches and competitors. Moscow: Alpina Pablisher, 2011.

6. Porter M. International competition. (1993) Moscow: Iternational Relationships

7. Prahalad C., Hamel G. The Core Competence of the Corporation //Harvard Business Review. Vol. 68. 1990. N 3. P. 79-91

8. Prebish R. Peripheral capitalism: are there any alternatives? (1992) Moscow, ILA RAN.

9. Russian grain union- URL: http://grun.ru/ (дата обращения: 06.03.2016).

10. Serova E. Agrarian reform in Russian at transformation period - http://www.ru-90.ru/ (05.05.2016).

11. Simanovskaya M., Silanteva E., Importsubmition in aspect of economic theories // Public administration. E-journal - 2016 - № 56. - P. 198 -219 